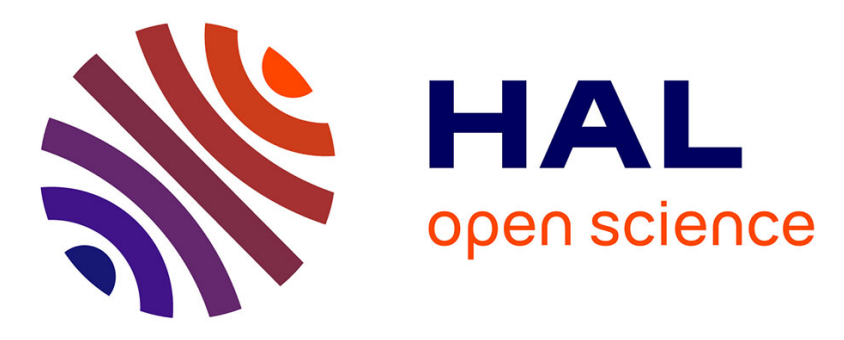

\title{
One hippopotamus and eight blind analysts: a multivocal analysis of the 2012 political crisis in the divided Republic of Mali
}

Baz Lecocq, Gregory Mann, Bruce Whitehouse, Dida Badi, Lotte Pelckmans, Nadia Belalimat, Bruce Hall, Wolfram Lacher

\section{To cite this version:}

Baz Lecocq, Gregory Mann, Bruce Whitehouse, Dida Badi, Lotte Pelckmans, et al.. One hippopotamus and eight blind analysts: a multivocal analysis of the 2012 political crisis in the divided Republic of Mali. Review of African Political Economy, 2013, 40, pp.343 - 357. 10.1080/03056244.2013.799063 . halshs-01395536

\author{
HAL Id: halshs-01395536 \\ https://shs.hal.science/halshs-01395536
}

Submitted on 10 Nov 2016

HAL is a multi-disciplinary open access archive for the deposit and dissemination of scientific research documents, whether they are published or not. The documents may come from teaching and research institutions in France or abroad, or from public or private research centers.
L'archive ouverte pluridisciplinaire HAL, est destinée au dépôt et à la diffusion de documents scientifiques de niveau recherche, publiés ou non, émanant des établissements d'enseignement et de recherche français ou étrangers, des laboratoires publics ou privés. 


\title{
One Hippopotamus and Eight Blind Analysts: \\ A multivocal analysis of the 2012 political crisis in the divided Republic of Mali \\ Extended Editors Cut
}

\author{
Baz Lecocq, Gregory Mann, Bruce Whitehouse, Dida Badi, Lotte Pelckmans, Nadia \\ Belalimat, Bruce Hall, Wolfram Lacher.
}

\section{Introduction}

In 2012, the political landscape in the Republic of Mali transformed rapidly, drastically, and unpredictably. The formation of a new Tuareg political movement - the National Movement of Azawad-in October 2010 and the return to Mali of Tuareg with military experience from the Libyan conflict in August 2011 - bringing along heavy weapons and logistical suppliesmade speculation on renewed violence on the part of separatist Tuareg inevitable. Indeed, Tuareg separatists launched attacks on Malian garrisons in the Sahara in January 2012. Mali had experienced such rebellions before. What nobody foresaw was that this renewed conflict would lead to a coup d'état by disgruntled junior officers; the near total collapse of Mali's army and most of its democratic institutions; the seizure of all of northern Mali by Tuareg rebels and foreign and local mujahideen; ${ }^{1}$ the precocious proclamation of an independent Azawad Republic; and the effective occupation of the north of the country by an alliance of Jihadi-Salafi movements who imposed their form of shari'a law on a suffering and largely recalcitrant population. Those events happened very quickly, and their effects will be felt for years. This article attempts to give an overview of the crisis in Mali as it unfolded through 2012, with particular attention to what was happening on the ground in Mali itself.

The Malian national mascot is the hippopotamus: a quiet but potentially dangerous mastodon whose name in the Bambara language is a homonym for the name of the country. At present, the Malian hippo is floating gravely wounded in murky and troubled waters. The current political situation in the country involves different political cultures, domains and systems, including Tuareg clan politics, a contested multi-party system based in Bamako, the

\footnotetext{
* This is an Authors' Original Manuscript of an article submitted for consideration in the Review of African Political Economy (copyright Taylor \& Francis); The Review of African Political Economy is available online at http://www.tandfonline.com/loi/crea20 (Article DOI not yet available).

Although the first two authors named carried out the editorial work necessary for this article, the article would not have been possible without the input of any of its contributors. Each of the authors therefore reserves the right to claim primary authorship over this article in personal bibliographies.

${ }^{1}$ As this article will make clear, several groups fought against the Malian government and sometimes against each other. They fall into two broad categories. The first, the Tuareg separatists known as the MNLA, are in rebellion against their own government; we refer to them as 'rebels.' Those in the second category are engaged in a violent jihad with ideological roots in Salafism. They see themselves as fighting for Islam, although the vast majority of their victims are Muslims who do not recognize their religion in the actions of these fighters. We refer to this second category as the mujahideen; some of them are in rebellion against their own government, but many are citizens of foreign countries. They are not therefore 'rebels.' As we argue below, individual fighters and commanders have shifted back and forth across the permeable boundary between these two categories, but we maintain it for analytical purposes.
} 
international domains of Franco-African relations, the position of ECOWAS (the Economic Community of West African States) and the ideology and effective networks of global jihad. No single scholar can claim full understanding of all these domains. Understanding is further hampered by a lack of reliable information on what happens on the ground, coupled with a good deal of deliberate or accidental misinformation. This article represents an attempt by a group of eight scholars, each of whom has studied one or two of the aspects that together make up a hugely complex beast, to pool our sources and analysis. In analogy to an old parable, the eight of us are like the blind scholars who, touching different parts of an object, each come up with a different explanation of its nature. We hope that in the discussion of our findings below we will clarify at least partly what the nature of the beast is. Our inquiry will remain incomplete. First of all, despite the unusually large number of contributors to this article, our view is not panoramic, while our vision is imperfect. Second, the situation in the Sahel continues to change in unexpected ways. Between the time of our writing and the publication of this article, the situation has already changed dramatically, as it undoubtedly will do again. This then is an exercise in contemporary history, culminating with international diplomatic efforts to organize a military intervention to be led by ECOWAS, authorized by UN Security Council resolutions (July and October 2012), and materially supported by France. At the time of writing, we did not think that this intervention would be effectively organised and operational before the first months of 2013 at the earliest. Events proved us right, although not in the fashion that we had anticipated. In its published form this article may serve as a historical background to this intervention. ${ }^{2}$

\section{A divided north}

Any real understanding of the crisis in northern Mali requires a locally grounded historical perspective. Deeply rooted social distinctions among the very diverse population of northern Mali are charged with ever-weightier political significance. The Tuareg and the Songhay represent the two largest groupings, although the region also hosts significant populations of Arabs and Fulbe, and smaller numbers of Bambara, Bozo, and Dogon. A more complex distinction in northern Mali attaches itself to essentially local ideas about racial difference. Grossly oversimplified, this discourse distinguishes between "white" Tuareg and Arabs, and "black African" Songhay and other communities. After independence, competing racial nationalisms emerged from roots that went much further back in time and which made exclusive claims. Tuareg nationalism expressed itself in two rebellions against the Malian state between 1963 and 1964, and again between 1990 and 1996. In the 1990s a form of Songhay nationalism emerged that explicitly countered Tuareg nationalism. In recent years, the relative absence of the state from the northern regions has not only sharpened the old tensions between the different northern communities ('black' vs. 'white', nomad vs. sedentary, Arabs vs. Tuareg, etc.), but especially those between the north and the south of the country. The effects of and reactions to this geographic division differ between communities. Despite the Flame of Peace Ceremony of March 1996, which ended an earlier Tuareg rebellion and which was intended as a powerful symbolic purification of relations in the country, the north and its divisions have remained an open sore on the body of the Malian

\footnotetext{
${ }^{2}$ In order to remain comprehensible for those not initiated in the politics of Mali and the wider Sahara, we have tried to avoid excessive detail in the names of places and actors, but in some cases these details are necessary. Except where footnotes to particular sources are given, all information comes from research conducted by telephone or over the internet, and in some cases through recent fieldwork in the region.
} 
hippo. In the previous decade, that sore became infected by foreign Salafi ideas and mujahideen, and by trans-continental networks of organised crime. From 2006 to 2009 Mali experienced renewed conflict with Tuareg dissident fighters. This renewed "rebellion" was largely grounded in tensions internal to Tuareg society. A peace accord signed in Algiers in 2006 turned out to be merely a prelude to further protracted fighting between Tuareg separatist fighters, mostly from the Kidal region, under the leadership of Ibrahim Bahanga and units of the Malian army composed essentially of Tuareg military officers and enlisted men, most of whom were of so-called 'imghad' social origins. ${ }^{3}$ The conflict ended in early 2009 with the retreat of Bahanga's men to Libya, a country to which many Tuareg, particularly those of the Kel Adagh federation, have deep ties. In 2011, Libyan rebels forced open Qadhafi's arsenals, which fell under the control of various militant groups, including Jihadi-Salafi organisations such as the Libyan Islamic Fighting Group. Between March and April 2011 AQIM (Al-Qaeda in the Islamic Maghreb) organised convoys from its camps in northern Mali to stock up on arms in eastern Libya, establishing a de facto link with their Libyan Jihadi-Salafi counterparts. ${ }^{4}$ At the same time, nationalist Tuareg networks centred around Ibrahim Bahanga also launched themselves in the race for Libyan arms, making use of their own contacts among Qadhafi's loyalist forces. Thus, two different armed movements with two different agendas were primed for action by the Libyan crisis. The influence of that crisis on events in Mali should not be overstated; any understanding requires some nuance. The Libyan revolution did speed up a process of remilitarisation in northern Mali after the relative peace since 2009, but in all likelihood, political developments in Mali itself would have led to an outbreak of separatist, or potentially jihadi, violence sooner or later. ${ }^{5}$

After the fall of Qadhafi in summer 2011, thousands of Tuareg of Malian origins left Libya for Mali. Some had made careers in the Libyan army, others had fought either as irregulars for Qadhafi or with the anti-Qadhafi rebels. Once back in Mali, these fighters joined various military organisations - including the Malian army - according to the factional logics of clan and class within Tuareg society. Former Libyan soldiers, led by future MNLA president Bilal ag Achérif and MNLA chief of staff Mohamed ag Najim, united with Tuareg separatists who had challenged Mali in 2006 and who fought for Qadhafi in 2011. In Mali, these men linked up with a group of young Tuareg from northern Mali who had founded a new political movement, the MNA (Mouvement National de l'Azawad; National Movement of the Azawad) in October 2010, and with a number of experienced Tuareg politicians. Thus the MNLA (Mouvement National pour la Libération de l'Azawad; National Movement for the Liberation of Azawad) was born in October 2011. For most of early 2012, the MNLA worked to win the attention of the outside world. Their media savvy political branch ensured that their nationalist narrative was heard, while leaving the nature of their relationship with the more silent Jihadi-Salafi movements in the region unclear.

\footnotetext{
${ }^{3}$ We have no space to develop this fully, but it is important to note that social tensions within Tuareg and Arab societies between on the one hand 'noble tribes' (such as the Tuareg Ifoghas and Arab Berabish) and 'tribeless lower classes' (such as the Tuareg imghad and the so called Lamhar or 'Tilemsi Arabs') on the other, are an important part of the conflict's dynamics.

${ }^{4}$ Jean-Yves Moisseron and Nadia Belalimat, "L'après-Kadhafi : nouveaux défis en Libye et au Sahel", in M. Mokhefi and A. Antil (eds.), Le Maghreb et son Sud: vers des liens renouvelés Ifri/ CNRS, 2013: 73-90.

${ }^{5}$ The ongoing instability in Libya - where the growing power of Salafi militias is hardly being curtailed - may continue to have effects in Mali, particularly in the form of greater cooperation, even integration, between AQIM and its Libyan counterparts.
} 
Those movements had themselves multiplied. AQIM had been present in the Malian Sahara for several years, although its roots are Algerian. In December 2011, a new organization known as MUJAO (the Movement for Divine Unity and Jihad in West Africa), composed mostly of southern Saharans, emerged from within its ranks. Another even more locally rooted Jihadi-Salafi movement had developed under the leadership of Iyad ag Aghali, a key figure in the Tuareg rebellion of the 1990s. Iyad ag Aghali had long broken with the project of national independence favoured by most of the MNLA leadership in favour of the greater integration of Tuareg society into the global Muslim world via, at first, peaceful means. Despite his global Muslim outlook, Iyad's social and political concerns remain largely local. His Islamist political project put him at odds with other leaders of the 1990s rebellion, including Bilal ag Achérif, who had integrated the MNLA, and Colonel Elhaj ag Gamou, the commanding officer of Mali's $8^{\text {th }}$ military region. At a meeting in November 2011, Iyad's proposal that the MNLA be reformed along shari'a lines was rejected, which led him to create Ansar Dine, a movement with a Jihadi-Salafi ideology akin to that of AQIM. Over the months to come, Ansar Dine would prove to be a loose alliance among formerly junior AQIM commanders, like Sanda ould Boumana, and Tuareg ex-separatist rebels from northern Mali, like Iyad ag Aghali, who supplemented their fighting forces on the basis of their own tribal affiliations and alliances. While Berabish Arabs from the Timbuktu area controlled the movement in that city, Kel Adagh Tuareg under Iyad ag Aghali's leadership controlled the Kidal Region. Collaboration between the two branches was probably somewhat loose and partly based on tribal affiliation. Rather than remaining one coherent, visible, and operative fighting unit controlling a particular zone, as Ansar Dine and MUJAO did, and as the MNLA attempted to do, AQIM katibas cooperated with Ansar Dine and MUJAO, leaving these organisations to be the public flag bearers of Jihad. Tensions between Ansar Dine and the MNLA would never be resolved, and a dynamic of fusion and scission, alliance and betrayal, would continue to characterize the relationship between anti-government forces in the months to come.

\section{Mali's Collapse}

Past Tuareg rebellions and a visibly corrosive situation in the Sahara had accustomed Malians to instability in the north. Yet a series of stunning defeats suffered by the Malian army in the North, notably at Aguelhok, where dozens of soldiers had their throats slit after surrendering, made the situation much more dramatic than in the past. An angry public-particularly the families of soldiers - found two objects for its rage. In Bamako and the nearby garrison town of Kati, crowds attacked the homes and businesses of Tuareg and other light-skinned Africans, especially targeting the property of suspected MNLA sympathizers. The other object was President Amadou Toumani Touré, "ATT" himself. Rumours of collusion between narco-traffickers and high-ranking members of ATT's government quickly morphed, and ATT was accused publicly of failing to arm and equip his soldiers, even of siding with the rebels. When the wives of soldiers castigated him on national television, ATT's already weakened authority suffered a mortal wound. His government continued to stagger towards presidential elections scheduled to be held in late April, elections which would have offered him an honourable exit from a shameful situation.

On 21 and 22 March, a mutiny in Kati became an improvised coup d'état. In Bamako, the collapse of ATT's regime was spectacular. What outsiders had perceived as a stable, inclusive government with healthy republican institutions was revealed, over the course of a few days in March, to be resting on a rotten foundation. So tenuous was its control that when a few 
dozen low-ranking soldiers and junior officers challenged ATT's leadership on $21 \mathrm{March}$, his power evaporated virtually overnight. After the mutineers stormed the presidential palace and state broadcasting centre that evening, Touré went into hiding. For two hours no one from Touré's inner circle even bothered to contact the mutineers to ask what they wanted. Only then did the soldiers decide to take power themselves. No sooner had they done so than the state security apparatus lined up behind them. The junta headed off any potential dissent by arresting senior military leaders, along with cabinet ministers loyal to Touré, within hours of taking over. For ordinary Malians, government officials and even key foreign governments, the question quickly became not how to restore the ousted president to office, but how to legitimize his departure in a constitutional manner. ${ }^{6}$ By the time of the coup Toure had lost nearly all legitimacy in the eyes of everyday Bamakois. Touré's 'rule by consensus' had become a mere euphemism for absolute rule with checks and balances existing only on paper while journalists and others were afraid to challenge the president's agenda. Meanwhile, the perception in Bamako was widespread that Touré's aversion to conflict extended to all areas of politics, rendering him unwilling to enforce the rule of law or to punish venality among those close to him. His reaction to challenges against state authority in the north since the late 1990s, and especially the 2006-2009 mutinous rebellion of Tuareg officers in the north, was seen as weakness out of step with notions of strong rule associated with Presidential power in Mali. He kept a tenuous peace by buying off northern leaders, but failed to deliver on promises to bring development to the north. He took millions of dollars of US military assistance intended to help drive out AQIM, but never went after the group's camps or members on Malian territory. The gangrene of corruption had long infected the army, where nepotism and profiteering ran amok. The outcome of elections was widely considered to be determined in advance, and voter turnout was consequently always low. Few Malians regretted ATT's departure, and the coup initially met with significant, although far from universal, support.

Days after the coup, the Malian army collapsed. With much of its general staff under arrest and key northern garrisons in mutiny, what remained of the army was chased from Kidal, Timbuktu, and Gao over the course of a weekend. Some two-thirds of the national territory fell into the hands of the MNLA and the mujahideen. On 6 April, an MNLA spokesperson in Paris prematurely declared the independence of the Azawad Republic. Two days later ATT formally resigned, leaving a de jure gap in the political structure in Bamako and a dangerous vacuum. In the immediate wake of the coup d'état, the junta attempted to overturn the core institutions of Mali's Third Republic, suspending Mali's 1992 constitution and calling for a sovereign national conference to chart a new course for the nation. Faced with stiff opposition from Mali's established political parties and from foreign governments - and notably the brief imposition of ECOWAS sanctions - the junta was forced to backpedal, reinstate the constitution and ultimately transfer power to a civilian government.

While Mali's political class had steadily and with near unanimity refused to collaborate with the junta's newly created CNRDRE (Comité national pour le redressement de la démocratie et la restauration de l'État; National Committee for the Rectification of Democracy and the Restauration of the State), one element within it felt empowered by the coup, particularly the vocal members of the anti-globalization Left as represented by a loose coalition of ex-student activists, trade unionists, members of the SADI (Solidarité Africaine pour la Démocratie et l'Indépendance; African Solidarity for Democracy and Independence) party, and others. To

\footnotetext{
${ }^{6}$ As early as March 21st, French Foreign Minister Alain Juppé called for a return to constitutional rule, but did not insist on that ATT be returned to power.
} 
them, the reinstatement of constitutional rule was the worst of outcomes. For a brief moment, it looked as if the coup had not brought the revolution they hoped for, but a return to the corrupt civilian leadership they condemned. That leadership was personified by President of the National Assembly Dioncounda Traore, an ex-Minister of Finance and stalwart of the ADEMA (Alliance pour la Démocratie en Mali; Alliance for Democracy in Mali) party that had dominated Malian political life in the 1990s. By virtue of his office, Traore became president when ATT resigned, and he was charged with forming a transitional government and organizing elections. Within days, a mob assaulted the elderly Traore in the presidential palace with the clear connivance of the security forces. Beaten nearly to death, Traore was evacuated to Paris for treatment. He would linger there for weeks, while the political situation in Mali festered and Prime Minister Cheikh Modibo Diarra struggled to establish a viable government. Diarra had been imposed as Prime Minister by ECOWAS negotiator President Blaise Compaoré of Burkina Faso, but he had multiple sources of support that Traore did not. Son-in-law of ex-President Moussa Traore (1968-1991), scion of a family whose political leadership extends back for generations, and a successful scientist with an international career at NASA and Microsoft Africa, Diarra was seen by many Malians as the rare rich man who had earned his money honestly and from the outside, rather than at the expense of others. However, by the same token, Diarra was widely regarded as beholden to junta leader Captain Sanogo and to Burkinabe President Compaoré. He proved to be politically tone deaf, quickly alienating much of Bamako's political class by excluding them from his government. 'Mali can collapse,' said a brash French diplomat speaking from Paris in July, 'and as long as Bamako remains, they will all squabble over scraps of power in Bamako." That diplomat claimed to be repeating something he had heard from one of his Burkinabe counterparts, but he endorsed a point of view widely shared. Until Traore returned and a new government of national unity was formed in August, the situation in Bamako stagnated and that in the north festered.

Months after the coup, military and civilian factions continued to struggle over what remained of the state. Having brutally extinguished a rebellion by disgruntled paratroopers affiliated with ATT in late April, Captain Amadou Haya Sanogo, leader of the junta, held the upper hand in a divided military that neither President Traore nor Prime Minister Diarra could control. This triangulated form of authority was inherently unstable, and real power lay in the garrison town of Kati. By December, Diarra had squandered virtually all of the support and good will he might once have enjoyed, and frustration with him had reached a breaking point in Bamako, Kati, and in foreign capitals like Paris and Washington. In mid-December, Captain Sanogo's men arrested Diarra, and he was forced to resign. At that point, Django Cissoko, who had served in the governments of both ATT and President Moussa Traore (1968-91), was named the new Prime Minister. The political system in Bamako was in disarray, and many northern politicians and displaced civilians accused both the junta and the civilian government of abandoning them. Meanwhile, the forces occupying the Northranging from the MNLA to AQIM-were no more united than those squabbling in the South.

\section{The rise of jihad in the Sahara}

As has been argued, the Tuareg rebellion of 2012 was much more than a simple revival of previous insurgencies. It was different not only militarily-doped as it was by Libyan arms and other weapons superior to those of the Malian army-but also ideologically. In the first

\footnotetext{
7 http://blog.slateafrique.com/post-afriques/2012/07/26/mali-une-classe-politique-pathetique-selonun-diplomate-francais/ Last accessed 19/10/12.
} 
months of 2012, divisions between the MNLA and the jihadist coalition of Ansar Dine and its allies had been temporarily subordinated to their shared desire to push the Malian army out of the North. Once that task was accomplished, with no small help-albeit unintended-from Mali's mutinous soldiers, rebels and mujahideen quickly fell to fighting one another. Within a few short months of the collapse of the Malian Armed Forces in April, the MNLA lost control of virtually the entire territory of Mali's three northern regions to a militarily superior alliance of Ansar Dine, AQIM, and MUJAO. The latter group had emerged in December 2011, and because its leader, Hamada Ould Mohamed Kheirou, is Mauritanian, was generally seen as a 'foreign organisation.' However, in the porous societies of the Sahara and the Sahel, such terms may not have great meaning, and several of MUJAO's most prominent members - such as the head of its police force-are Malian nationals of Songhay or Lamhar Tilemsi Arab origin, and its leadership is suspected of being deeply involved in the trans-Saharan drug trade. ${ }^{8}$ Rich in weapons and flush with cash from trafficking narcotics and seizing European hostages for ransom, these movements soon publicly discarded the MNLA's nationalist claims to the Azawad and competed politically and militarily with the MNLA on the ground.

The possible alliance between the MNLA and the different Jihadi-Salafi movements unraveled quickly, but it considerably clouded the analysis of both outside observers and regional actors. Several factors indicate that such an alliance existed, whether or not one actually obtained. Ironically, most important among those factors were the active media campaigns of the MNLA, which claimed attacks and victories in the north that were not theirs. Assaults on Aguelhok, Tessalit and Kidal were all carried out by an alliance of JihadiSalafi movements-Ansar Dine and various AQIM units - who did not directly claim their victories. MNLA participation in them remains unclear; the strongest evidence for it remains the statements of the MNLA itself. All witnesses concur, however, on the sizable presence of mujahideen, while AQIM elements circulated among the population to herald the arrival of jihad in the Azawad. The MNLA's own military fortunes were more mixed. For instance, the MNLA spent months in the Timbuktu area without being able to take the city. Before the MNLA could launch its final assault, local Berabish Arab militia leaders essentially handed the city over to AQIM to prevent it from falling into the hands of the Tuareg separatists. Likewise despite being present at the conquest of Gao-when rape was widespread and the pillaging of medical facilities systematic - the MNLA did not control the city centre, which fell into the hands of mujahideen. It now appears that the only battle the MNLA fought and won alone was in Ménaka. The confusion around the relation between the MNLA and the mujahideen was enhanced by the media strategy of Ansar Dine leader Iyad ag Aghali, who in fact counted on the MNLA's media capacities. In hindsight, it becomes clear that Iyad used the MNLA's media outreach as a curtain to hide his own politically toxic alliance with AQIM in his capture of the north (by the same token, the MNLA declared AQIM its primary enemy, even though the Malian army was its first target). Only in March 2012 did Ansar Dine release a video on YouTube claiming their victories in Tessalit, Aguelhok and Kidal, and explaining their goals to the world. ${ }^{9}$ Ansar Dine's military victories led to the defection of a core of experienced MNLA fighters from the Kidal Region to Ansar Dine, and the MNLA appeared ever weaker on the ground. MUJAO fighters chased the MNLA from its strongholds at the edge of the city in June 2012. An attempt to recapture Gao from the mujahideen in November 2012 failed dramatically, and defections continued. Throughout the second half of 2012, the MNLA was increasingly strapped for cash, but the movement still had a number of fighters-

\footnotetext{
${ }^{8}$ Lacher, Wolfram. "Organized Crime and Conflict in the Sahel-Sahara Region", in The Carnegie Papers, Washington: Carnegie Endowment for international peace, 2012.

${ }^{9} \mathrm{http}: / /$ www.youtube.com/watch? $\mathrm{v}=$ tr6C49Zvhlc\&list=FLmv9mp53nsWTTdzv5Qo9caw\&index=21\& feature=plpp_video. Last accessed 09/11/12.
} 
especially from Tuareg tribes from the area between Tin Zawaten and Ménaka-and some support among populations in the Kidal Region and parts of the Gao Region.

While Tuareg nationalism has been a force in Saharan politics for decades, the rise of political Islam with a Salafist orientation is much more recent. The acceptance of Islamist tenets by a minority within the larger Tuareg political landscape must be understood in the context of the broader 'globalization' of Tuareg society over the last two decades or more. Major factors of political-religious transformation include the arrival in the late 1990s of the South Asian Islamist movement Tablighi Jama'at - which strongly condemns recourse to jihad in a Muslim society in the absence of certain necessary legal conditions - the emergence of AQIM's ancestor, the Algeria-based GSPC (Groupe Salafiste pour la Predication et le Combat, Salafist Group for Preaching and Combat) in 2003, and the launching of the US Pan-Sahel Initiative, a counter-terrorism program focused on military training in the wider region. Over the last decade or more, long-standing practices of international smuggling and migration have become more intense, complex, and profitable, while the technological infrastructure has been transformed. All these factors complement the previous experience of many Malian Arab and Tuareg as migrants in the Maghreb, Libya and West Africa. The subsequent sociopolitical changes have reshaped their perception of their political situation according to the new global position of their homeland. The Tuareg organised in Ansar Dine are of the conviction that only their Salafi ideology can unify the various Tuareg clans, the different ethnic groups in the region, and even the whole of Mali. These political convictions propose an alternative to both the Malian nation-state, riddled with corruption and nepotism, and the political ideal of Tuareg independence, which so far has been unable to overcome the divisive clan structures within Tuareg society. Iyad ag Aghali, the leader and founder of Ansar Dine, has personal experience with these political realities. His initial adherence to the Tablighi Jama'at can be partly explained by his disappointment in the failure of nationalist political projects and armed rebellion in the 1980s and '90s. Nevertheless, many Ansar Dine members may be fighting not so much for shari'a but due to their personal or tribal loyalty. A rumour that Ansar Dine once considered changing its name to reflect its origins within the Ifoghas tribe suggests that this 'tribal current' may have been strong within the movement. ${ }^{10}$ It may also underscore ag Aghali's ideological contradictions - for example, asserting that he wished to see Mali under shari'a, rather than an independent Azawad - as well as his history of pragmatic adaptation to political developments.

Another factor distinguishing the current Saharan conflict from earlier episodes of rebellion is the sheer scale of resources available to the mujahideen, quite apart from the arms and munitions looted or purchased from Libyan arsenals. With money won over the last decade by holding European hostages for ransom, as well as by "taxing" or offering "protection" to smugglers of narcotics and other commodities, the mujahideen were able to procure and maintain firepower and mobility superior to both the Malian Army and the MNLA. They have been able to afford the expensive illegally trafficked supplies (especially fuel and ammunition, but also food and medicines, most likely coming from Libya and Algeria) needed to sustain their effort. Media reports as well as research confirmed that early in the conflict the mujahideen offered high salaries to new recruits, thus attracting both inexperienced youths from all the Northern ethnic groups and experienced fighters from the MNLA. The mujahideen's superior equipment in part explains their initial victories on the battlefield, as well as how they routed the MNLA from the few positions it held in June and

\footnotetext{
${ }^{10} \mathrm{http} / / /$ www.nord-mali.com/index.php/home/2076-ansar-eddine-change-dappellation ?tmpl=component\&print $=1 \&$ page $=$. Last accessed 18/10/12.
} 
July 2012. The mujahideen also used their cash reserves to pay for food relief aid, fuel and medicines to run local hospitals and power stations, thereby creating some goodwill among the local population. Early in their occupation of northern towns and cities, they increased their popularity still further by compensating merchants for their losses when they were forbidden to sell cigarettes or alcohol, by financing marriage ceremonies for young couples to poor to wed, and by offering high bride prices to marry local women, at least some of whom accepted the offer, thereby embedding the organisation deeper in the local community. The focus on AQIM and its allied movements the MUJAO and Ansar Dine has long been on their involvement in criminal activities in the Sahara: the abduction of European tourists, aid workers and mining employees, and the trafficking of various drugs. AQIM in particular has received millions of euros in ransoms over the last decade, and while its relation to smuggling and narco-trafficking is not clear-some analysts insist it is not at all involved-MUJAO in particular is thought to be deeply implicated in the latter. The question of what the JihadiSalafi movements needed the money for is now answered: to occupy a large territory in West Africa and to rule it according to their concept of shari'a.

\section{Frontiers and frontlines}

Yet another factor distinguishes the current situation from earlier rebellions. With over 400,000 refugees and internally displaced people (IDPs), the humanitarian crisis surpasses by far any of the previous conflicts the region has seen. Unlike during previous conflicts, when Tuareg and Arab communities were most severely affected, in 2012 all communities of the north were concerned. In the first half of the year, the inhabitants of the effected zones in the Mopti and Gao Regions - Songhay, Peul, Tuareg, Bozo, Dogon alike-fled en masse to Niger, Burkina Faso, and southern Mali. Many of the inhabitants of the Timbuktu Region departed for Mauritania, where their constant influx created food insecurities in the UNHCRrun camps. ${ }^{11}$ While those who fled to most neighbouring countries had an internationally recognised status as refugees that triggered UNHCR involvement, Algeria enacted its own refugee policy - via the Algerian Red Crescent - for those who crossed the border from the Kidal region. The conflict also provoked an exodus of internally displaced persons, as many town dwellers sought refuge with nomad relatives in the bush, while others fled to live with relatives in Bamako and other cities under government control.

A clear indicator of the acute threat the current crisis poses to the territorial integrity of the Malian state is the fact that the town of Douentza and its environs became the frontline in the conflict in an early stage. While previous conflicts in the north were largely situated on the north bank of the Niger river, with only short incursions into the Niger Bend, this time Douentza, in the central Mopti Region, was continuously occupied by various insurgent forces. MNLA rebels, the majority of whom were Tuareg native to the area, occupied the town in mid-May. ${ }^{12}$ However, the symbolic position of Douentza as 'the border of the Azawad Republic' only lasted a few weeks. When fighting erupted between MUJAO and the MNLA in late June, the latter were forced to retreat from Gao and Douentza to Ménaka. MUJAO's occupation of Douentza in August was facilitated by the Malian Armed Forces' failure to claim the city when the MNLA abandoned it in early July. In addition to demonstrating the

\footnotetext{
${ }^{11} \mathrm{http}: / /$ www.wfp.org/node/3516/3900/279035. Last accessed 17/10/12.

${ }^{12}$ Parts of this section draw on reports by Boukary Sangaré who visited the Douentza region several times during both MNLA and MUJAO occupation. With the help of Prof. M. de Bruijn, he published some reports online. See, e.g., http://www.ascleiden.nl/?q=news/la-situation-actuelle-au-nord-du-maliarticle-et-photos. Last accessed 11/02/13.
} 
incapacity of the Malian Armed Forces to defend its territory against insurgent forces, the episode also casts doubt on the limited territorial claims of the MNLA, while bearing out the stated intentions of the Jihadi-Salafis that their Jihad is not limited to northern Mali. When the Malian Armed Forces retreated as far south as Konna, 120km southwest of Douentza, it was widely feared that the mujahideen would continue to advance in the direction of MoptiSevaré. This is, indeed, what came to pass in January 2013.

\section{Life under Shari'a rule}

Soon after the collapse of the Malian army, the remaining civilian population of the north was submitted to Jihadi shari'a rule. Sedentary and urban communities were especially affected by the absence of the state and its health, education and security infrastructures, as well as by the disruption of economic life. Pastoral nomad communities, always more removed from the state, were less immediately affected. Although outbreaks of cholera were reported, and although the region was far from enjoying food security, the large-scale famine that many predicted early in the year did not in the end materialize. First of all, contrary to all predictions, the 2012 rainy season was a good one, breaking the drought of previous years. Especially in the pastoral zones the sanitary and alimentary situation was not as bad as it was expected to be. Pastures were abundant, making the pastoral economy perhaps the only viable economic alternative to the emerging war economy. While harvests in the south were good, crops in the north were far below average, making for a precarious alimentary situation outside the pastoral bush. Legal commerce was considerably disrupted as the main source of imports and exports in the north, Algeria, formally closed its borders. However, the long standing commercial and kin relations with communities in neighbouring countries, together with the retreat of the Malian customs services, facilitated the supply of basic foodstuffs in the north, albeit at staggering prices. In the Niger Bend, less dependent on Algerian imports, the price of a $100 \mathrm{~kg}$ bag of millet was double that of 2011, rising from 16,000 to 32,000 FCFA.

MNLA and mujahideen systematically dismantled the state bureaucracy and destroyed the archives of the civil administration in what seems to have been a premeditated tabula rasa. Mujahideen particularly targeted symbols of secular francophone administration. In Douentza, schools, prisons, medical centers and banks were closed from March to July 2012, when the MNLA left the town. The administrative void had disastrous effects. Tensions between different populations - Fulbe, Dogon, Songhay, and Tuareg - became more lethal as small arms were traded in high quantities, and as official mediation was absent. It was reported that criminals who had escaped the prisons in northern cities took advantage of the absence of security forces by engaging in looting. Songhay in Timbuktu blamed both the MNLA and local Tuareg who lived on the outskirts of town for much of the looting in the immediate wake of the conquest of the north. Similar dynamics have been reported for other northern towns such as Diré and Gao. The MNLA also robbed civilians as they fled the north at makeshift roadblocks, creating further animosity for the movement and its fighters. The mujahideen replaced the already fragile economy of the north and what little prospect of salaried employment existed with a war economy. Various accounts concur on the forced recruitment of child soldiers and youths of Tuareg and Songhay origins around Timbuktu, Tessalit and Gao. The military barracks at Amachach in the Kidal Region became a training ground for youngsters. In Douentza, which does not appear to have been a zone of recruitment, relations between inhabitants and mujahideen were precarious. Superficial tolerance toward the mujahideen seemed to be much more linked to the security crisis that destabilized the city than to strategic and ideological alliances chosen by its inhabitants. 
The situation of women in the north was particularly dramatic. Many were forced into seclusion or exile, having had to abandon their economic, political and other activities. In those zones under the direct control of Ansar Dine and its ally AQIM (Timbuktu and Kidal) men and women alike were flogged for violating the mujahideen's rules on socializing, smoking, or listening to music. Women in particular were subject to strict rules of modesty and veiling. In the most drastic of a series of huddud punishments, a couple of pastoralist parents who were not legally married were stoned to death for adultery in Aguelhok. In Timbuktu, Gao, Kidal, and Wabaria, women, sometimes joined by young men, protested against the rules of the mujahideen, who repressed these demonstrations with beatings, whippings or by firing in the air. When Ansar Dine fighters broke up a women's demonstration in Kidal on June $6^{\text {th }}$, they provoked a second public protest by women, men and children in In Khalil the following day. Led by female MNLA leaders who had been imprisoned in Bamako for their support of the movement, an association of "women of the Azawad" had organized the marches in Kidal and In Khalil to denounce the mujahideen's application of the shari'a and their suppression of Tuareg culture. This cultural resistance was further manifest in the composition of very critical poems that women (and men) would exchange via social networks and cellular phones (using Bluetooth technology), denouncing both the imposition of Salafi-Jihadi rule and the manipulation and financing of the mujahideen by foreign powers.

\section{Local opposition}

Even if, for most of 2012, the momentum seemed to be with the mujahideen, they had to contend with local counterparts who held greater legitimacy and social leverage in northern societies. Within Tuareg society, the MNLA represented the most obvious counterweight to the Salafi-Jihadi coalition, as it appeared to be the only force capable of raising effective armed opposition to the mujahideen (barring the Malian army units commanded by Tuareg officers like Alhajj Ag Gamou, who remained sidelined for many long months). Moreover, the MNLA enjoyed some historical legitimacy based in previous rebellions in Tuareg society, and it had considerable support among women and younger men. The traditional chieftaincy, especially that of the Ifoghas, represented another important counterweight, as did local religious authorities representing a quietist Sunni and Sufi approach to Islam. The most reputed representatives of these chieftaincy and the ulema took active positions against the mujahideen. Local Muslim authorities have condemned the Salafi recourse to jihad and violence in the application of Shari'a. Intallah ag Attaher, the supreme chief of the Kel Adagh, supported their declarations. Clearly alluding to AQIM, Intallah called on more than one occasion for armed movements from outside the Azawad to leave the region. These calls were formalised in written declarations after meetings held respectively in Gao in April, in Kidal in June, and in Anefis in September, but their very repetition underscores their lack of effect.

Iyad ag Aghali's rejection of the traditional authorities' open call to distance himself from AQIM, as well as the different attempts to unite Ansar Dine and MNLA formally, further added to the ambiguity of his political position. By far one of the most experienced political figures in Mali's political quagmire, Iyad has pursued exactly this kind of ambiguity to place himself in the centre of every possible outcome of the conflict. The attempts to reconcile Ansar Dine and MNLA can be partly explained by Iyad's attempts to destroy the MNLA from within and to clear the last secular obstacle withholding him from reshaping Tuareg politics in an Islamist mould. Some observers hold that his relations with other Jihadi-Salafi movements 
have been dictated by the same policy and goals: to hollow out the legitimacy and position of these movements leaving Ansar Dine as the sole viable alternative. However, although the presence for much of 2012 of Alghabbas ag Intallah-Intallah ag Attaher's son and 'Executive Chief' of the Ifoghas tribe - in Ansar Dine's leadership might seem to reflect a division within the Ifoghas tribe over the movement, it is far more likely to reflect an old strategy of the Ifoghas chiefly family to 'join and influence' to their own advantage and goals, a strategy in which they have excelled since the early colonial occupation of the Sahara. In short, and paradoxically, Alghabbas' presence might have been intended to curb ag Aghali's ambitions.

As for the other communities of the north: in Bamako, a largely Songhay organization called the COREN (Collectif des Ressortissants du Nord; Collective of Northern 'Natives'), which includes a number of prominent northern politicians, has organized demonstrations and played an active role in keeping the issue of the occupation of northern Mali in the public eye. They attempted to put pressure on the government in Bamako to act to retake the north and to accept the intervention of ECOWAS military forces. They have also encouraged the initial stages of the training of Songhay civilian militias such as the Ganda Koy and Ganda Izo by the Malian Army. Born of COREN's frustration with the Malian state's failure to act to retake the north, the deployment of militias as a vanguard for re-conquering lost territory seemed unlikely to be very effective militarily, while risking enormous problems in terms of ethnic conflict.

Similar developments could be noted for Douentza and its surroundings, where people elaborated new forms of self-governance in order to address the governmental void by taking matters into their own hands. Migrants from the area who were living in Bamako took the first initiatives. Using the cultural association DEENTAL as their platform, they lobbied to have Douentza included as a destination for humanitarian aid, which at first was only destined to the three northern Regions. Those living in France and other foreign countries lent their moral support to that campaign through social media. After the MNLA retreated from Douentza, Ibrahim Dicko, a member of the local Fulani chieftaincy, initiated a Brigade for Security and Defence that aimed to protect the populations by tracking thieves and burglars. ${ }^{13}$ In June, the Malian army trained some of the members of this group and over the summer they allied themselves with other vigilante movements, such as the Ganda Izo and Ganda Koy. Despite the Malian Army's training and logistical support, the MUJAO had no difficulty at all in disarming them when they took the city in June 2012. Nonetheless, the Malian army continued to work to integrate local ethnically based militias (other than, of course, the largest of them, the MNLA).

Just as one ethnically based political movement often begets another, opposing movement, attempts by the mujahideen to frame their movement as an Islamic one provoked opposition from Muslim leaders and scholars across Mali. The characterization of Malian Islam as tolerant, moderate, or mystical fails to capture the universal terms in which many in northern Mali (Songhay, Tuareg, Arab and Fulbe) view their religious culture. Many resent claims by the mujahideen and other Salafists to be bringing "true Islam," as if it needed to be introduced for the first time. But at the same time, many are able to engage Islamists on their own terms, with expertise and knowledge that the Islamists are bound to respect since it often surpasses their own religious training. This does not mean that the Islamist vision of Islam is fully

\footnotetext{
${ }^{13} \mathrm{http}: / /$ www.ascleiden.nl/?q=news/la-situation-actuelle-au-nord-du-mali-article-et-photos. accessed 11/02/13.
} Last 
acceptable to the majority of people in northern Mali, whatever their ethnic identity. To the contrary. But it does help to explain the relative peace of the region in the latter half of 2012, once the mujahideen expelled the MNLA. The mujahideen's claims to be engaged in the establishment of an Islamic state in Mali that enforces Shari'a law is not premised on the exclusion of any ethnic or racial group from the north. The MNLA, to the contrary, is generally seen as a Tuareg dominated movement that seeks a Tuareg controlled independence of the Azawad. That is unacceptable to the majority of the potential 'Azawadi' population. Thus, contrary to the MNLA, the Jihadi-Salafists offer potential grounds for discussion to local Muslim intellectuals. Mahmoud Dicko, who heads Mali's influential Haut Conseil Islamique (Islamic High Council), attempted to engage in a dialogue with the mujahideenfor example, by visiting Gao in early August to meet with the MUJAO leadership - but later expressed his frustration with their abortive dialogue. In Timbuktu, known for its sophisticated and well-developed Islamic intellectual culture, the possibility existed of engaging with the Jihadi-Salafist movements on religious grounds that many people feel quite comfortable with. However, actual attempts at dialogue seem to have been frustrated, and by the end of 2012, prominent Muslim leaders in Bamako received death threats from the JihadiSalafists.

On the local level in the north, the mujahideen found themselves religiously opposed by Sufi Muslims whose holy shrines they desecrated and destroyed in Timbuktu and Douentza; by the Tablighi Jama'at who denied them the right to wage jihad; and by local Malian Muslim organisations, Islamist or other, who engaged the mujahideen in their own terms. These organisations were further supported within Mali by a host of Muslim organisations. Political opposition centred around the traditional chieftaincy, which denied the validity of authority based on Shari'a; diasporic political communities of refugees; and the MNLA, whose political project centred around secular nationalist notions of statehood. To varying degrees, those positions were supported by the local populations of different ethnic groups, but not without many ambiguities. Just as the Tuareg and Arab communities were divided over support for separatists or autonomists or for the Malian state, support for the mujahideen was also uneven (bearing in mind that many leading figures of MUJAO were Lamhar or Tilemsi Arabs, and Ansar Dine was largely composed of and led by Tuareg). The other communities of the north felt strong resentment toward the MNLA and its separatist project, as well as the violence and looting surrounding their 'conquest' of the north. This led in some instances to a benign vision of the Salafi tenets of the mujahideen, but that vision proved hard to reconcile with the violent huddud punishments and petty harassments they inflicted on ordinary citizens, the overwhelming majority of whom were themselves Muslim. The open resistance of women, and Tuareg women in particular, is perhaps the best indication of the degree of discontent with the pretentions of the mujahideen.

\section{Outside Intervention}

The application of corporal huddud punishments by the mujahideen made for extraordinarily bad press abroad. Combined with direct threats against neighbouring states-notably Algeria and Mauritania, but also Nigeria - and against France (long one of AQIM's avowed targets), public floggings, amputations and especially the stonings in Timbuktu, Gao, Ansongo and Aguelhok provoked revulsion across Mali and around the world. Spurred on by France in particular, and feeling-indeed being-immediately threatened by the Islamist groups controlling the Sahara, Mali's neighbours in ECOWAS as well as those like Mauritania and Algeria that do not form part of the organization, experienced great pressure to take military action themselves. Throughout 2012, the political conjuncture in Bamako, as well as complex 
regional relations, stymied an intervention that might otherwise have appeared inevitable. However, ECOWAS' maladroit talk of intervention as early as March and April 2012 provoked intense anger from a small but vocal — and even dangerous - minority within Mali (organised in the umbrella of COPAM; la Convergence patriotique pour le Mali, Coordination of Patriotic Organizations in Mali) towards the organization, its Chairman Ivoirian President Alassane Dramane Ouattara and its designated mediator, Burkinabe President Blaise Compaoré. Allied with a military jealous of its prerogatives, those activists made the possible deployment of ECOWAS troops to Mali-and particularly to Bamako, where they would protect the civilian government - an extremely sensitive political issue.

The failure of the regional security apparatus precedes the recent crisis and was indeed one of the permissive factors that allowed a local rebellion to become a regional and even transcontinental crisis. Among the factors that allowed the situation in northern Mali to deteriorate in 2010 and 2011 - the formative phase for both the MNLA and Ansar Dine - the absence of effective military and security cooperation among the states of the region played a major role. Regional efforts to address the growing jihadi presence in the Sahara, such as the Algerian-led CEMOC (Comité d'état-major opérationnel conjoint; Joint Military Operations Centre) in Tamanrasset, stalled completely. Among the reasons for that failure figure the longstanding rivalries between North African states, notably between Algeria and Morocco, as well as (until the fall of the Qadhafi regime) between Algeria and Libya. The most significant obstacle, however, was the inaction of the Malian leadership vis-à-vis AQIM and criminal networks, which caused tensions with Mauritania and Algeria. These surfaced, for example, in repeated unilateral interventions by the Mauritanian army in northern Mali during 2010 and 2011. Further afield, European governments contributed to regional tensions by not only paying millions of Euros in ransom money, but also pressuring the Malian and Mauritanian governments into releasing convicted AQIM members in exchange for the liberation of hostages. In February 2010, for instance, Mali's release of a Mauritanian, a Burkinabe and two Algerian nationals as part of the liberation of French hostage Pierre Camatte caused a major diplomatic spat with Mauritania and Algeria, two countries that those militants had targeted.

West African regional relations also complicated efforts to address the current conflict in northern Mali. Immediately after the March coup, ECOWAS and the Burkinabe President Blaise Compaoré took the lead on regional attempts at mediation and plans for intervention in the conflict, while the African Union (AU) was paralyzed by an internal power struggle over leadership that took months to resolve. However, Algeria and Mauritania-by far the two most influential states in northern Mali-opposed ECOWAS plans for military intervention and disapproved Compaoré's mediation efforts in the conflict (which in any case were scarcely palatable to many Malians). At the same time, Algeria stubbornly refrained from taking a leading regional role on northern Mali beyond merely insisting on a negotiated solution. In northern Mali, among governments in the Sahel, as well as in Europe, the motivations behind the Algerian stance became the object of much speculation and suspicion. Finally, Mali's eastern neighbour, ECOWAS member Niger, found itself in a double position. President Mamadou Issoufou publicly supported the idea of a UN sanctioned international intervention. However, Nigerien Tuareg led him to understand that they would oppose their government should it support an ECOWAS intervention. In case of active Nigerien support for such a mission, Nigerien Tuareg threatened to take up arms in support of their Malian brethren. As a result, President Issoufou had to walk a tightrope between foreign and domestic threats. By September, however, as the situation on the ground deteriorated and the 
mujadhideen took the upper hand from the MNLA, he emerged as a vocal supporter of foreign intervention in Mali.

Throughout 2012, as the crisis deepened and the involvement of external actors increased, their distinct agendas became ever more apparent. In addition to holding talks with armed groups, Burkinabe President Compaoré was also involved in negotiations over the release of hostages through his adviser, a man well connected in Tuareg and Arab political circles and trade networks from Mauritania to Niger. Moreover, in September 2012, media reports referring to French intelligence claimed that the MUJAO had received arms shipments via Burkina Faso; wounded MNLA fighters had already sought care in the country, and Ouagadougou hosted an important group of MNLA in refuge. Compaorés ambiguous position was matched only by Algeria, which in September 2012 initiated its own mediation efforts with Ansar Dine, in direct competition with Burkinabe efforts. Tensions north of the Sahara rose as well. Increasingly blunt accusations that Morocco was manipulating the MUJAO to target Algeria and gain a foothold in the conflict appeared in the Algerian media. Qatar, which many believe provided material support for both the MUJAO and Ansar Dine, also sought to claim a mediating role in September 2012. The absence of a serious, disinterested interlocutor was felt all the more keenly when U.N. Secretary General Ban KiMoon named former Italian Prime Minister Romano Prodi as his special envoy to the Sahel. Many observers agreed that Prodi lacked the experience and even the language skills to serve as an effective mediator, and the motivations behind his appointment appear to have had more to do with the politics of Brussels and Turtle Bay, home of the United Nations, than with his capacity to effect change in Bamako or Kidal. A rather naive October report by the Secretary General and two irresolute Security Council resolutions in October and December only deepened the sense that the U.N. could or would do little to resolve the crisis.

In sum, despite cries of alarm from Malians themselves, as well as from their neighbours with the most at stake-figures like President Issoufou of Niger and President Macky Sall of Senegal-foreign powers left the Malian crisis to stagnate for over nine months until it became well and truly an international emergency. This must be recognized for what it is: a failure of diplomacy for which many international actors bear responsibility, including notably ECOWAS, the AU, and the UN. In 2013, efforts by Mali's neighbours and other foreign actors to pull the hippo safely on to dry land risk wounding it further, especially since - at the time of writing-those efforts privilege armed intervention over coherent concertation on its political goals.

\section{Conclusion}

Throughout most of 2012, the Malian hippo floated helplessly in waters that grew murkier by the day. Blind as we are, we have groped at it and attempted to identify it and its ailments. Any conclusion would be provisional, but two points emerge. First, for all its international and Saharan dimensions, the roots of the crisis were first and foremost Malian. It is true that, via actions they took or refused to take, Mali's neighbours and other foreign powers made the crisis a regional one. But the wounds of the North, re-opened in the 1990s, had long remained unhealed on the Malian body politic. In recent years, that sore had been further infected by passive or active participation in the drug trade by high-ranking military officers and political figures, by Bamako's laissez-faire attitude to those in the North it considered its political proxies, and by its failure to counter the presence of foreign mujahideen and their local recruits. While the problems plaguing the north have been relatively visible for several years, outside observers failed to diagnosis the hippo's internal ailments, especially the degree of 
corruption pervading a political system in which many of them were deeply invested. The fall of the Touré government in just a few days in March - an event welcomed by many Malians - can only be explained by mounting dissatisfaction during Touré's second term in office, combined with a real lack of faith in the democratic process represented by the cancelled April elections. The current patch on Mali's wounded democracy-in the form of an interim government led by Cissoko and presided over by a barely constitutional President Traore - is scarcely adequate as a bandage, let alone capable of allowing the wound to heal. Our second point is this: any real understanding of this complex crisis must look simultaneously out from the Sahara and up from Bamako. That is to say, it must be concurrently attentive to regional and international factors at work in the Sahara and aware of the deeply local, even personal nature of the political crisis there, and in Kidal and Timbuktu in particular. Understanding the Sahara as an 'extraverted' political space, in the terms of Jean-François Bayart, should not preclude adopting a highly localized, even granular analysis of the political forces at work, notably amongst the Kel Adagh Tuareg and among the Arab tribes from the region. ${ }^{14}$ The same could be said for Bamako, where myopia afflicts both an inward-looking 'political class' - a widely used term itself indicative of the rent-seeking that characterized political life under ATT-and an equally self-absorbed army, which in the months after it took power engaged in murderous internal struggles while failing to protect civilians in the North. In a word, a comprehensive view of the Malian crisis must be binocular, while remaining attentive to the inevitable blind spots in analyses too often bifurcated into 'northern' and 'southern' perspectives. We argue that the first step in helping the hippo to heal has to be an objective and synthetic diagnosis of what ails it.

\footnotetext{
${ }^{14}$ J.-F. Bayart, "Africa in the World: a History of Extraversion," African Affairs 99, 395 (2000): 217267.
} 